\title{
The Relationship Of Covid-19 Prevention Behavior With Quality of Life in Mutihan, RT 05, Wirokerten Village, Banguntapan Bantul, Yogyakarta Year 2020
}

\author{
Zulchaidir K Lewenussa \\ Master of Public Health Program of Public Health Faculty, Muhammadiyah University of Jakarta \\ K.H. Ahmad Dahlan St, Cireundeu, Ciputat South Jakarta, 151419 \\ E-mail: zulchaidirlewenussa@gmail.com
}

\begin{abstract}
In 2020 the spread of Covid-19 from person to person will be the main source of transmission, so the spread will become more aggressive. The enormous ability of this virus to infect and spread is evidenced by the note that so far there are still many people infected with Covid-19 with an increasing number. Cases in Indonesia also continue to increase, until March 29, 2020, there have been 1,115 cases with 102 deaths, while the largest number of cases of the COVID-19 outbreak in Yogyakarta is in Bantul district, Banguntapan sub-district with a total ODP of 150 people, PDP (1 died, 1 recovered, 6 are positive, and 24 are still under surveillance). To determine the relationship between COVID-19 prevention behavior and quality of life in Dusun Mutihan RT 5 Wirokerten, Banguntapan, Bantul, Yogyakarta. This type of research is a quantitative descriptive study with a cross-sectional approach. The sampling technique in this study was random sampling with as many as 65 samples taken. Based on the statistical results using the chi-square test, it was obtained X2 count of 28.502a, a $P$ value of $.000(P-0.10)$ which indicates that there is a relationship between covid-19 prevention behavior and quality of life in Mutihan village rt 05 Banguntapan Bantul Yogyakarta. There is a relationship between Covid-19 prevention behavior and quality of life in Dusun Mutihan Rt 5 Wirokerten, Banguntapan, Bantul, Yogyakarta.
\end{abstract}

Keywords: Behavior, Covid 19. Quality of life. 


\section{INTRODUCTION}

Coronavirus is an RNA virus with a particle size of $120-160 \mathrm{~nm}$. This virus mainly infects animals, including bats and camels. Before the COVID-19 outbreak, 6 types of coronavirus could infect humans, namely alphacoronavirus 229E, Severe Acute Respiratory Illness Coronavirus (SARS$\mathrm{CoV}$ ), and the Middle East Respiratory Syndrome Coronavirus (MERS-CoV) (Susilo et al, 2020).

Coronavirus or better known as Corona Virus Disease (COVID) 19 is a disease that first appeared in China in early December 2019. As of March 28, 2020, the number of confirmed cases of COVID-19 infection reached 571,678 cases. Initially, the most cases were in China, but currently, the most cases are in Italy with 86,498 cases, followed by America with 85,228 cases and China with 82,230 cases. This virus has spread to 199 countries. Deaths from this virus have reached 26,494 cases. The death rate from this disease reaches $4-5 \%$ with the most deaths occurring in the age group over 65 years. Indonesia reported its first case on March 2, 2020, which was suspected to have been infected by a foreigner who visited Indonesia. Cases in Indonesia also continue to grow, as of March 29,2020 , there have been 1,115 cases with deaths reaching 102 people. Indonesia's mortality rate is $9 \%$, including the highest mortality rate. Based on available data, the age of patients infected with COVID-19 ranged from 30 days to 89 years.

According to a report of 138 cases in Wuhan City, the age range was 37-78 years with a mean of 56 years (42-68 years) but ICU patients were older (median 66 years (57-78 years) than non-ICU patients (37-62 years). years) and 54.3\% men. Reports of 13 confirmed COVID-19 patients outside Wuhan City showed a younger age with a median of 34 years (34-48 years) and 77\% men.(Respirology indonesia 2020).

The great ability of this virus to infect and spread is evidenced by the record that so far there are still many people infected with Covid-19 with an increasing number. (Setiawan, 2020).

This study uses a random sampling technique with a total sample of 65 respondents. Researchers distributed questionnaires using a google form and filled in by the community of mutihan rt 5.

\section{METHODS}

The research is quantitative descriptive with a cross-sectional approach. The sampling technique in this study used the Random Sampling technique with a total sample of 65 respondents. Researchers distributed questionnaires using a google form and filled in by the people of Dusun Mutihan RT 5. 


\section{RESULTS AND DISCUSSIONS}

Frequency distribution of respondent characteristics based on age 19-38 years as many as 30 respondents (46.2\%), aged 39-58 years as many as 31 respondents (47.7\%), aged 59-79 years as many as 4 respondents $(6.2 \%)$.

Table 1. Frequency Distribution of Respondents Characteristics Based on Age, Gender, and Occupation of Dusun Mutihan RT 5 Wirokerten Banguntapan Bantul Yogyakarta.

\begin{tabular}{lll}
\hline Age & Frequency & Percentage \\
\hline $19-38$ age & 30 & 46,2 \\
\hline $39-58$ age & 31 & 47,7 \\
\hline $59-79$ age & 4 & 6,2 \\
\hline Total & 65 & 100 \\
\hline
\end{tabular}

The frequency distribution of respondents' characteristics based on female sex was 38 respondents (58.5\%), which were male as many as 27 respondents $(41.5 \%)$.

Table 2. Frequency Distribution of Respondents Characteristics Based on Gender of residents of Dusun Mutihan RT 5 Wirokerten Banguntapan Bantul Yogyakarta Gender

\begin{tabular}{lll}
\hline Sex & Frequency & Percentage \\
\hline Women & 38 & 58,5 \\
\hline Men & 27 & 41,5 \\
\hline Total & 65 & 100 \\
\hline
\end{tabular}

From the table below, it is known that from 65 respondents who were examined, the respondents who worked as civil servants were 1 person (1.5\%) respondents who worked as WORKERS were 18 people (27.7\%) respondents who worked as FARMERS were 1 person (1.5\%) respondents who worked as PRIVATE as many as 16 people (24.6\%) of respondents who work as IRT as many as 18 people (27.7\%) of OTHER respondents as $11(16.9 \%)$.

Table 3. Frequency Distribution of Respondents Characteristics Based on Occupations of the residents of Dusun Mutihan RT 5 Wirokerten Banguntapan Bantul Yogyakarta Occupation

\begin{tabular}{lll}
\hline & Frequency & Percentage \\
\hline Civil Servants & 1 & 1.5 \\
\hline Laborer & 18 & 27.7 \\
\hline Farmer & 1 & 1.5 \\
\hline Private & 16 & 24.6 \\
\hline Housewife & 18 & 27.7 \\
\hline Others & 11 & 16.9 \\
\hline Total & 65 & 100.0 \\
\hline
\end{tabular}

The level of prevention behavior of residents of Dusun Mutihan RT 5 Wirokerten Banguntapan Bantul Yogyakarta is low as many as 13 respondents $(20.0 \%)$, high as many as 52 respondents $(80.0 \%)$. 
Table 4. Frequency Distribution of Respondents Based on the level of prevention behavior of residents of Dusun Mutihan RT 5 Wirokerten Banguntapan Bantul Yogyakarta

\begin{tabular}{lll}
\hline & Frequency & Percentage \\
\hline Low & 13 & 20.0 \\
\hline High & 52 & 80.0 \\
\hline Total & 65 & 100.0 \\
\hline
\end{tabular}

Mutihan Hamlet, RT 05 Wirokerten, Banguntapan Bantul, the majority are in the medium category with a total of 39 people with a percentage (60.0\%) while the minority is in the low category with a total of 12 people with a percentage ( $18.5 \%)$ from the table above, it can be seen that the quality of life in Mutihan Hamlet RT 05 Wirookerten Banguntapan Bantul the most dominant is in the medium with a percentage $(60.0 \%)$. The table belowshows that the opinion of respondents based on the quality of life variable in

Table 5. Frequency Distribution of Respondents Based on Quality of Life Variables in Dusun Mutihan RT 05 Banguntapan Bantul Yogyakarta

\begin{tabular}{lcc}
\hline & Frequency & Percentage \\
\hline Low & 13 & 20.0 \\
\hline High & 52 & 80.0 \\
\hline Total & 65 & 100.0 \\
\hline
\end{tabular}

Table 6. Chi-Square Test Results Relationship of Knowledge with Preventive Behavior

\begin{tabular}{cc}
\hline Uji Corelasi & Nilai Sig \\
\hline Chi-square & 0,000 \\
\hline
\end{tabular}

Based on the results of the statistical test table 4.6 using the Chi-Square, it was obtained that $\mathrm{X} 2$ was calculated, namely $28,502 \mathrm{a}$, the P-Value was $0.000(\mathrm{P}-0.10)$, indicating that there is a relationship between covid-19 prevention behavior and quality of life in the mutihan village rt 5 Wirokerten Banguntapan Bantul, Yogyakarta. This study is following research conducted by (Evi 2013) that there is a very significant relationship between the behavior of preventing hypertension complications and the quality of life. So it can be concluded that the higher the prevention behavior, the higher the quality of life. The lower the preventive behavior, the lower the quality of life. This research is equivalent to research conducted by (wayan 2019.) That DM patients who have preventive behavior in the sufficient category have 4.73 times to experience acute complications in DM compared to those in the good category. These results show that the preventive behavior carried out or implemented in the mutihan $\mathrm{rt} 5$ hamlet is following what is set by the protocol regarding covid-19 prevention measures such as wearing masks, maintaining distance, staying at home, washing hands, and others. . With the implementation of the preventive measures taken above, it can improve the quality of life of the mutihan community, especially in RT 5 because the people of Dusun Mutihan 
RT5 feel that during the pandemic they feel fine physically, and spiritually because the hamlet community.

Mutuihan swiftly took precautions so that they could ease concerns in their neighborhood about the COVID-19 pandemic that occurred. This research is following research, (adliani 2015.) Preventive behavior is very influential on a person's quality of life, but preventive behavior against a disease (virus) is also influenced by several factors including public awareness of the importance of health and knowledge about the prevention process. So that prevention is carried out as desired or can improve a person's quality of life, Covid-19 prevention behavior is a response to prevent disease, for example walking using a mask, social distancing, and washing hands with soap, including behavior not to transmit disease to others. If behavior and health are combined, then healthy behavior is obtained, which means knowledge, attitudes, and proactive actions to maintain and prevent the risk of disease, and protect oneself from the threat of disease.

\section{CONCLUSIONS AND SUGGESTIONS}

Based on the test results with the chi-square test, it was found that the significant value was 0.000. So in this study, it can be concluded that there is a relationship between preventive behavior and quality of life with the Asymp value. Sig. $0.000<$ P-0.10. The suggestions from this research are:

\section{For Educational Institutions}

This research can be an additional reference and can be used as basic data in developing further public health research so that there are more and more studies examining the relationship between COVID-19 prevention behavior and quality of life in students and other ages.

\section{For the Community}

So that people take better care of their health and implement preventive behavior so they don't get infected with the covid 19 outbreak, if this outbreak is considered trivial, it will have a big impact on the residents of Mutihan RT 5 knowledge. The public needs to know about covid so that people can make decisions inappropriate behavior to break the chain of transmission of covid 19. It is hoped that the people of Mutihat RT 5 will always add insight regarding the prevention of the covid 19 outbreak, because the higher the preventive behavior applied, the higher the quality of life they get.

\section{For Further Researchers}

It is hoped that further research can be carried out regarding the analysis of factors related to the prevention behavior of COVID-19 with the quality of life and developing the problems that exist in the community related to preventive behavior and quality of life. 


\section{REFERENCES}

Adliyani, Z. O. N (2015). Pengaruh Perilaku Individu Terhadap Hidup sehat.

Evi vestabilivy (2013) 'Hubungan Perilaku Pencegahan Komplikasi Hipertensi dengan Kualitas

Hidup dan Stabilitas Tekanan Darah pada Pasien Hipertensi di Puskesmas Kecamatan Pondok

Gede, Kota Bekasi Tahun 2013.

Https://www.alodokter.com/ketahui-cara-untuk-mencegah-penularan-virus-corona

Jogjaprov (sebaran-covid 19 jogjaprov.go.id). "Jumlah Sebaran Covid 19 di Yogyakarta.

KBBI (2012) KBBI, kbbi.

Nofitri, N. F. M. (2013) 'Gambaran Kualitas Hidup Penduduk Dewasa pada Lima Wilayah di Jakarta'

Notoatmojo, S. (2010) 'Konsep perilaku kesehatan', Promosi kesehatan, teori dan aplikasi.

Notoatmojo, S. (2015) 'Motedologi Penelitian Kesehatan'

Nursalam (2017) Metodologi Penelitian Ilmu Keperawatan

Persatuan Dokter Paru Indonesia (2020) “diagnosis dan penatalaksana covid 19" https://www. persi. or.id/ images /2020/ data/ buku_pneumonia_covid19.pdf

Priyoto (2014) 'Teori sikap dan perilaku dalam kesehatan dilengkapi contoh kuesioner

Pudiarifanti, N., Pramantara, I. D. and Ikawati, Z. (2015) 'Faktor-Faktor yang Mempengaruhi Kualitas Hidup Pasien Gagal Jantung Kronik'

Respirologi Indonesia,Handayani (2019) jurnal respirologi. Org / index. Php / jri / article / view / 101. Vol.4 N0.2

Ririn, P. (2014) 'Gambaran gaya hidup pada lansia di dusun blimbing desa sukorejo kecamatan sukoorejo kabupaten ponorogo'.

Setiawan (2020). “Penetapan Karantina Wilayah Menurut Pandangan Legal Positivisme Dalam Rangka Pencegahan Dan Pemberantasan Pandemi Corona viris disease". Program Magister Ilmu Hukum, Universitas Muhammadiyah Malang.

Suardana, I. W., Mustika, I. W. and Sri Utami, D. A. (2019) 'Hubungan Perilaku Pencegahan dengan Kejadian Komplikasi Akut pada Pasien Diabetes Melitus'

Sugiyono (2017) 'MetodePenelitian Kuantitatif, Kualitatif dan R\&D. Bandung

Susilo, Dkk (2019). "Tinjauan Literatur Terkini Corona virus disease 2019: Review of current Literatures. Jurnal penyakit dalam indonesia. Vol.7 No.1.

'WHOQOL-BREF' (2010) in Handbook of Disease Burdens and Quality of Life

Word Helth Organization (WHO) 2020. "Corona Virus Disease"

Winardi, J. (2014) 'Teori Organisasi \& Pengorganisasian', Teori Organisasi \& Pengorganisasian.

World Health Organization (2004) 'The World Health Organization Quality of Life (WHOQOL)BREF', World Health Organization.

WHOQOL grup dalam (Billington.D. dkk 2010) The New Zealand World Healt Organisation Quality Of Life

Yuliza, W. T., Hardisman, H. and Nursal, D. G. A. (2019) 'Analisis Faktor yang Berhubungan dengan Perilaku Pencegahan HIV/AIDS Pada Wanita Pekerja Seksual di Kota Padang. 